\title{
Effect Of Image Therapy On Reduction Of Anniversary Of DIII Students Midwifery Dealing With Writing Scientific
}

\author{
Nurlina ${ }^{*}$, Ilhamsyah², Rahmatullah ${ }^{3}$ \\ Departemen of Mental Health Nursing, Stikes Panrita Husada Bulukumba, Indonesia1 \\ Nursing Department, Universitas Islam Negeri Alauddin Makassar,Indonesia ${ }^{2}$ \\ S1 Nursing Study Program, Stikes Panrita Husada Bulukumba, Indonesia ${ }^{3}$
}

*Corresponding Autor : nurlinapanrita@gmail.com

\begin{abstract}
According to World Helth Organization data, there are around 47.5 million people in the world who are affected by severe anxiety, in Indonesia alone there are around 14 million people aged 15 years and over, it is very possible to experience anxiety, overcoming anxiety by drawing activities is the right way to convey what which becomes a burden on the mind that causes anxiety through the process of scratching the image. The purpose of this study was to determine the effect of drawing therapy on reducing anxiety in D III midwifery students facing scientific papers at Stikes Panrita Husada Bulukumba 2018. This type of research is quantitative quasi-experimental with pre-test and post-test design methods. This study used a purposive sampling technique with research instruments using the HARS scale. This research was conducted for two meetings within 7 days. The paired T-test results obtained the first meeting $=0.001$ ( $p$-value $<0.005)$ and the second meeting the paired $\mathrm{T}$ paired value $=0.001(\mathrm{p}$-value $<0.005)$. The study concludes that there is an effect of drawing therapy on reducing anxiety in midwifery DIII students facing scientific writing exams at Stikes Panrita Husada Bulukumba 2018.
\end{abstract}

Keywords: Anxiety, Drawing Therapy

\section{INTRODUCTION}

Mental health in the form of anxiety is still one of the significant health problems and many individuals who have been targeted in the world with increasing populations and levels of triggers nowadays anxiety has become a common phenomenon, according to WHO data, there are about 35 million people affected by depression, 60 million people have bipolar disorder, 21 million suffer from schizophrenia, and 47.5 million suffer from severe anxiety (WHO, 2016). In line with this, a group of health studies, namely the national comorbidity study, reported that 1 in 4 people met the criteria for at least 1 anxiety disorder. anxiety can occur at any age with different stressors. Anxiety disorders are the most common clinical diagnostic disorders experienced by adolescents. Anxiety disorders affect $6 \%$ to $20 \%$ of children and adolescents in developed countries and are one of the most common psychological problems Anxiety is a type of mental disorder that 
most often occurs in the world with a prevalence of more than 15\% (Baredero, Dayrit, \& Maratning, 2016).

In Indonesia itself, namely, According to (Riskesdes, 2013), the prevalence of mentalemotional disorders with symptoms of depression and anxiety in Indonesia is 6\% more than 14 million people aged 15 years and over and especially in the special area of Yogyakarta is the prevalence with the highest emotional mental disorders. and become one of the dominant problems of this nation which has various life problems that are felt in this developing country. In a study related to the causes and ways of dealing with anxiety, namely in (Marseto \& Bachtiar, 2007) found the fact that anxiety can be overcome by focusing on the positive side of a situation or situation being faced, it can make positive emotions can be maintained and prevent emotions negativity appears so that a person will be able to face situations that threaten and cause anxiety. There are many kinds of causes for anxiety that arise such as things that are considered threatening or are considered difficult to do such as school exams, campus exams and various similar things, or more simply can be said everything that allows there is a stressor.

Scientific writing or commonly abbreviated as KTI is something that must be passed to become a midwife that is very likely to be frustrated, scientific writing can be interpreted as a work or the fruit of someone's thoughts about something he is researching. More specifically, it can be interpreted as a writing in which there is an investigation, observation, data collection, and data processing obtained from a good research and following the rules and research ethics. Scientific paper research can be divided into, field research, laboratory tests, or literature review based on logistical and empirical methods (Wagiran, 2011). In scientific writing, it is divided into two, namely case studies, in the form of writing KTI with results and also clinical method exams, namely the application of classroom laboratories, clinical laboratories and clinical practices which are then commonly called scientific papers for clinical examination methods, according to Pusdiknakes (2015) in (Novitasari, 2010). These tests are usually the cause of anxiety and must be treated appropriately. There are various kinds of problem solving for anxiety, one of which can be done by generating a sense of joy and creating it to the individual experiencing anxiety.

According to the American art therapy association in (Mahardika, 2015), art therapy or drawing therapy is an intervention to support mental health that uses art media, creative processes, and works of art produced to explore feelings, reconcile emotional 
conflicts, increase self-awareness, manage behavior and addiction, develop social skills, improve reality orientation, reduce anxiety, and increase self-esteem in a group or individual setting. Similar to the research above according to Setyoadi \& Kushariadi (2011) in (Setian, Wiyana, \& Erwanto, 2017) drawing therapy or commonly referred to as art therapy is a complementary therapy and encourages someone to describe or visualize emotions and thoughts that cannot be expressed through the word is then expressed through drawing activities. In line with that, Indonesian therapy has begun to be known because very satisfying results are found, usually some are collaborated with the art of drawing that can be applied, this art therapy has often been used for patients with mental disorders such as emotional disturbances (Mahardika, 2015).

The initial survey which was conducted on 27 March 2018 to 10 female students with interviews who will face the scientific paper exam (KTI) with the clinical examination method at the Panrita Husada Clinic, obtained data from 10 people, 9 of whom admitted to being anxious about the exam and 1 of them admitted not anxious because they are confident and claim to have studied hard and are confident that they can pass the test well. The purpose of this study was to determine the effect of drawing therapy on reducing anxiety in D III midwifery students facing scientific papers at the Panrita Husada Bulukumba School 2018.

\section{MATERIAL AND METHODS}

The type of research used in this research is pre experimental designs, with a one group pretest-posttest approach (Susila \& Suyanto, 2014). Which aims to determine the effect of drawing therapy on reducing anxiety in D III midwifery students facing scientific papers at Panrita Husada Bulukumba 2018. Population is the overall line (the whole) unit of analysis whose characteristics will be known. Population members are called population elements and are divided into the sampling population and target population (Hastono \& Sabri, 2013). The population in this study were all of the midwifery students of Stikes Panrita Husada Bulukumba who would face a scientific paper examination as many as 85 female students.

In this study, the type of research used was purpose sampling, namely sampling was carried out only based on the consideration of the researcher who considered the elements desired or needed already in the sample members taken at the time of the study. The sample in the research to be carried out is midwifery students who will face 30 scientific papers. Research instruments or commonly called data collection tools. In 
making research instruments, it refers to research variables, operational definitions and data measurement scales that have been chosen with consideration (Suyanto, 2011). The research used a research instrument in the form of a questionnaire using an ordinal measuring scale. Univariate analysis, namely analyzing tables containing one variable, this analysis only provides a percentage of existing data, when the data has been entered into a frequency distribution table or table with one variable, this analysis can be carried out and this analysis is done through the help of an application. SPSS (Syamsyuddin, Muriyati, Asnidar, \& Sumarni, 2015).

This analysis was conducted to find a relationship between two or more variables, namely the dependent and independent variables (Syamsyuddin, Muriyati, Asnidar, \& Sumarni, 2015). To measure the effect of the independent variable on the dependent variable, a paired $T$ test was used with a significance level of $5 \%$ or 0.05 . if the p-value $<0.05$ then Ho is rejected and Ha is accepted, which means that there is an influence between the independent variable on the dependent variable, whereas if the pvalue $>0.05$ then $\mathrm{Ha}$ is rejected and $\mathrm{Ho}$ is accepted which means that there is an influence between the independent variable on the dependent variable.

\section{RESULTS}

Table 1. Distribution of the number of respondents based on the age of the D III midwifery student

\begin{tabular}{ccc} 
Age & Frequency (f) & Percentage (\%) \\
\hline 19 & 1 & 6.7 \\
20 & 15 & 50.0 \\
21 & 11 & 36.7 \\
22 & 2 & 6.7 \\
\hline Amount & 30 & $\mathbf{1 0 0 . 0}$
\end{tabular}

Based on table 1, it can be seen that the age of the respondents is at the age of 20 years, namely as many as 15 people (50.0\%) and in this table it can be clearly seen that the lowest number was at the age of 19 and 22 years, respectively 2 people (6.7\%). 
Table 2.Distribution of the number of respondents based on the level of anxiety among D III midwifery students facing KTI before and after being given therapy

\begin{tabular}{ccccc}
\hline \multicolumn{5}{c}{ First intervention } \\
\hline \multirow{2}{*}{ Stress level } & $\begin{array}{c}\text { Prequency } \\
\text { (f) }\end{array}$ & $\begin{array}{c}\text { Percentage } \\
(\%)\end{array}$ & $\begin{array}{c}\text { Frequency } \\
\text { (f) }\end{array}$ & Percentage (\%) \\
\hline Don't worry & 12 & 40.0 & 24 & 80.0 \\
Light anxiety & 11 & 36.7 & 4 & 13.3 \\
Being anxious & 3 & 10.0 & 1 & 3.3 \\
Anxious & 4 & 13.3 & 0 & 0 \\
Great anxiety & 0 & 0 & 1 & 3.3 \\
\hline Amount & 30 & 100.0 & 30 & 100.0 \\
\hline
\end{tabular}

Based on table 2, it was found that the anxiety level of the D III midwifery student before being given drawing therapy was the highest score in the not anxious category, namely 12 people (40.0\%) and the lowest level of anxiety of the respondents was the moderate anxiety category, namely 3 people (3.3\%), based on table 5.2 It was also found that after being given drawing therapy, the highest score was in the not anxious category, namely as many as 14 people (80.0\%) and the lowest level of anxiety of respondents was the category of moderate anxiety and one person each (3.3\%).

Table 3. Distribution of the number of respondents based on the level of anxiety in D III midwifery students facing second intervention KTI before and after being given therapy

\begin{tabular}{ccccc}
\hline \multicolumn{3}{c}{ Second intervention } \\
\hline \multirow{2}{*}{ Stress level } & \multicolumn{2}{c}{ Pre } & \multicolumn{3}{c}{ Post } \\
\cline { 2 - 5 } & Frequency & Percentage & Frequency & Percentage \\
& $(\mathrm{f})$ & $(\%)$ & $(\mathrm{f})$ & $(\%)$ \\
\hline Don't worry & 8 & 26.7 & 19 & 63.3 \\
Light anxiety & 11 & 36.7 & 9 & 30.3 \\
Being anxious & 5 & 16.7 & 0 & 0 \\
Anxious & 5 & 16.7 & 1 & 3.3 \\
Great anxiety & 1 & 3.3 & 1 & 3.3 \\
\hline Amount & $\mathbf{3 0}$ & $\mathbf{1 0 0 . 0}$ & $\mathbf{3 0}$ & $\mathbf{1 0 0 . 0}$ \\
\hline
\end{tabular}

Based on table 3, it was found that the level of anxiety in D III midwifery students after being given drawing therapy was the highest score in the mild anxiety category, namely as many as 11 people (36.7\%) and the lowest level of anxiety of respondents was the severe anxiety category for 1 person each (3.3\%). and based on table 5.3 it was also found that the level of anxiety in D III midwifery students after being given therapy drew the highest score in the not anxious category, namely, 19 people (63.3\%) and the lowest 
level of anxiety of the respondents was the category of severe anxiety and one person each. (3.3\%).

Table 4. Distribution of the effect of drawing therapy on reducing anxiety in D III midwifery students in facing exams

\begin{tabular}{|c|c|c|c|c|c|}
\hline \multirow[b]{2}{*}{ Stress level } & \multicolumn{4}{|c|}{ Paired differences } & \multirow[t]{2}{*}{ p Value } \\
\hline & mean & Std.deviation & $\mathrm{T}$ & Df & \\
\hline First intervention & 0.633 & 0.890 & 0.966 & 29 & 0.001 \\
\hline Second intervention & 0.800 & 0.805 & 1.101 & 19 & 0.000 \\
\hline $\begin{array}{l}\text { The first intervention } \\
\text { before the second } \\
\text { intervention after }\end{array}$ & 0.433 & 0.971 & 2.443 & 29 & 0.0021 \\
\hline
\end{tabular}

intervention. where in the first intervention the mean value (0.633), standard deviation (0.890) and p value (0.001) were obtained, while in the second intervention the mean (0.800), standard deviation (0.805), and p-value (0.000) were obtained. In this case, using the paired $\mathrm{T}$ test, the first intervention value was 0.001 and the second intervention value was 0.000 , so it was concluded that there was an effect of drawing therapy on reducing anxiety in D III midwifery students facing scientific papers at Panrita Husada Bulukumba because the two measurement values obtained were $<0.005$. And to find out the average value of the first and second interventions, the measurement of the first intervention before and the second intervention after which the results consisted of the mean (0.433), the standard deviation value (0.971), and the p value (0.021) which indicated that there was also a the relationship between the two interventions, namely the first intervention and the second intervention.Based on Table 1 the number of respondents in this study amounted to 36 respondents from nurses in the ICU. Characteristics of the study subjects included gender, employment status, years of service, and age. The sex of the respondent is female (86.1\%), the employment status of the respondent is honorarium (66.7\%), the length of service of the respondent is 1-5 years (55.6\%) and the age of the respondent is an early adult of $26-35$ years (55, 6\%).

\section{DISCUSSION}

In this study, it can be seen that there is an effect of drawing therapy on reducing anxiety in D III midwifery students facing scientific papers at Panrita Husada Bulukumba 2018. By using the paired $\mathrm{T}$ test with a confidence level $(=0.005)$, the $\mathrm{P}$ value was 
obtained $<(0.001$ first intervention, 0.000 second intervention $<0.005)$ according to this result, Ho was rejected and Ha was accepted, so it was concluded that there was a significant effect of drawing therapy on reducing student anxiety. III Midwifery Stikes Panrita Husada Bulukumba .. Other studies that support the above description are those conducted in other similar studies, it is also said that there is an effect of drawing therapy with a reduction in stress levels, namely the results of the questionnaire show that the post-test results in the control group after therapy show There is an increased mean which means there is an influence, the average value seen in this study is from 19.28 to 22.22 (Setiana, Christian, \& Rizki, 2017).

\section{CONCLUSION}

The effect of drawing therapy on reducing anxiety for D III midwifery students facing scientific papers at the Panrita Husada Bulukumba Station 2018 ... Hopefully the research results can increase knowledge for students at STIKES Panrita Husada Bulukumba. And this therapy can be used as a way to deal with anxiety problems.

\section{REFERENCES}

Baredero, m., Dayrit, m. w., \& Maratning, a. (2016). kesehatan mentak psikiatri. jakarta: buku kedokteran EGC.

Hastono, s. p., \& Sabri, l. (2013). statistik kesehatan. jakarta: raja grafindo persada.

Mahardika, b. (2015). implementasi metode art therapy dalam mencerdaskan emosional siswa . jurna kependidikan .

Marseto, \& Bachtiar. (2007). pengaruh pelatihan berpikir positif terhadap penurunan tingkat kecemasan mengahadapi ujian nasional pada siswa siswi SMA. jurnal psikologi integratif, 44.

Novitasari, F. (2010). praktek klinik kebidanan dalam upaya penapaian kompotensi mahasiswa pada asuhan kebidanan.

Riskesdes. (2013).

Setian, D. a., Wiyana, C., \& Erwanto, R. (2017). pengaruh art theraphy (tereapi menggambar) terhadap stress pada lansia. jurnal kebidanan dan keperawatan .

Setiana, d. a., Christian, w., \& Rizki, e. (2017). pengaruh art theraphy terhadap stres pada lansia. jurnal kebidanan dan keperawatan .

Susila, \& Suyanto. (2014). metode penelitian epidemiologi. yogyakarta: bursa 
ilmu kerangkajen.

Suyanto. (2011). metodologi dan aplikasi penelitian keperawatan. yogyakarta: nuha medika.

Syamsyuddin, Muriyati, Asnidar, \& Sumarni. (2015). pedoman praktis metodelogi penelitian internal. ponorogo: wade group.

Wagiran. (2011). pengembangan profesi guru melali karya tulis ilmiah.

World Health Organization. (2016). 